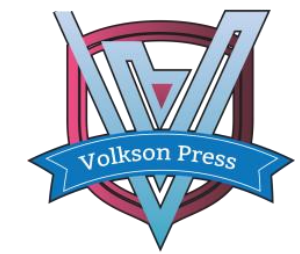

Contents List available at VOLKSON PRESS

Clean Water,Air\&Soil(CleanWAS)

DOI : http://doi.org/10.26480/cleanwas.01.2017.17.19

\title{
Study on the Hard Water Softening Treatment and Its Mechanism Based on the Solubility Product
}

\author{
Yonggang Zeng \\ School of Architecture and Civil Engineering, Chengdu University, Chengdu, China \\ Corresponding Author: 122054216@qq.com
}

This is an open access article distributed under the Creative Commons Attribution License, which permits unrestricted use, distribution, and reproduction in any medium, provided the original work is properly cited

\section{ARTICLE DETAILS}

\section{Article History:}

Received 02 october 2017

Accepted 06 october 2017

Available online 11 october 2017

Keywords:

Solubility product, hard water, softening, permanent hardness

\section{ABSTRACT}

The paper was based on the knowledge of solubility product(Ksp) which is applied to softening treatment of hard water, and emphatically analyzed the mechanism of transforming permanent hard water into temporary hard water by using Ksp principle. Then the following conclusion were drawn: The transformation of the permanent hardness which belong to the same type is suitable for the conversion of $\mathrm{CaSO}_{4}$ to $\mathrm{CaCO}_{3}$ in hard water, and the transformation of different types of permanent hardness is suitable for the transformation of $\mathrm{CaCl}_{2}, \mathrm{MgCl}_{2}$ and $\mathrm{MgSO}_{4}$ in hard water. In this paper, the conversion efficiency of $\mathrm{CaSO}_{4}$ to $\mathrm{CaCO}_{3}$ was studied by experiments, and the amount of transformation was predicted by linear regression equation. In the prediction, the maximum absolute error was 0.67 , the maximum relative error was $0.1 \%$, the average absolute error was 0.073 , and the average relative error was $0.028 \%$. Therefore, the prediction accuracy is high and reliable.

\section{Introduction}

The rapid development of science and technology, promoting the development of industry, improving the quality of people's life. As an important part of industrial production and daily life, water is also getting more and more attention. The problems of hard water not only affect the industrial production, often bring security risks, but also affect people's health in a certain extent. How to use the simple way to make the concentration of calcium, magnesium ion concentration decrease in hard water, become a topic of our concern.

\subsection{The Concept of Hard Water}

The hard water is the water which containing much soluble calcium and magnesium ions, for example well water and spring water. The hardness of water is the content of salt in the water, that is, the content of calcium salt and magnesium salt. Groundwater such as well water and spring water contain much salt, belongs to hard water. In hard water, the Ca and $\mathrm{Mg}$ exist in the form of carbonate, bicarbonate, chloride and nitrate etc. The water contain more salt, the greater the hardness is, and vice versa[1].

\subsection{The Classification of Hard Water}

According to the content of calcium carbonate and magnesium carbonate in water(To couched in the forms of $\mathrm{mg} / \mathrm{L}$ or $\mathrm{ppm}$ ), the hardness of water is divided into four grades: soft water, 0-60ppm, a little hard water, 60$120 \mathrm{ppm}$, hard water, $120-180 \mathrm{ppm}$, the extremely hard water, $181 \mathrm{ppm}$ or more. The hard water also can be divided into temporary hard water and permanent hard water. The temporary hard water is the acid saline solution formed by $\mathrm{Ca}$ and $\mathrm{Mg}$ carbonate. The salt solution containing calcium bicarbonate and magnesium bicarbonate, the salt can be removed by boiling. Permanent hard water is the salt solution formed by the oxides of $\mathrm{Ca}, \mathrm{Mg}$ sulfate salt solution containing calcium sulfate, sulfuric acid magnesium or calcium chloride, magnesium chloride salt solution. The heating method cannot translate the permanent hard water into soft water by salt precipitation[2].

\subsection{The Harm of Hard Water}

Hard water does not cause direct harm to human health. The hard water quality of drinking water is rich in mineral elements needed for human body. It is a significant channel for people to supplement trace elements such as $\mathrm{Ca}, \mathrm{Mg}$, etc. But for the infant, infant's gut has not yet fully developed, if we use high hardness hard water to brewing infant formula which contains protein and mineral nutrients, excessive intake of mineral elements can cause indigestion.

In daily life, drinking hard water will have a certain impact on human health. People never drinking hard water before drinking it occasionally, can cause gastrointestinal dysfunction, the so-called "not yet acclimated to the new place". Use hard water to cook fish and vegetables will destroy or reduce the nutritional value of food for not easy to cook. Use hard water to brew up tea will change it's color, flavor and taste.

More specific, use hard water to wipe mirror would make it full of water stains. Washing clothes with hard water will reduce the washing efficiency of the soap and detergent. It also will cause water heaters, humidifiers and other equipment's pipe blocking, flow reduced, life expectancy shortened. Long-term use of hard water washing will not only make the white bathtub yellowing and on the surface of water using appliances is covered with scale plaque. It will cause human's skin become dry, rough and itching. The hair washed by hard water will dry, knotted and not easy to comb[3].

And in industrial production, Use boiler boiling hard water in long-term will form a pot of scale, hind the heater conduct heat. When the pot scale is too thick, it will cause the local overheating of the boiler, even cause the boiler cracked and explosion accident. At the same time, because the hard water problem, in industry, it cost tens millions of money each year due to equipment, pipeline 's repair and replacement[3].

\section{The Conventional Treatment Method of Hard Water}

\subsection{Electromagnetic Method}

In water, with a certain electric or magnetic field to change the characteristics of the ion, even change deposition rate of $\mathrm{CaCO}_{3}$ or $\mathrm{MgCO}_{3}$ and physical characteristics during the deposition to prevent the form of hard water scale. Its main function is to affect the physical properties of the scale within a certain range. So the use of water after the treatment has a certain limitations in use time and scope. Mainly used for commercial circulation cooling water treatment, for instance, central air- 
conditioning[4].

\subsection{Ion Exchange Method}

Many new synthetic ion exchange agents can be used to exchange $\mathrm{Ca}^{2+}$, $\mathrm{Mg}^{2+}$, etc. in the water. The $\mathrm{Na}^{+}$in the resin can remove the $\mathrm{Ca}^{2+}$ and $\mathrm{Mg}^{2+}$ in water by ion exchange. The saturated resin can be regenerated by $5 \%$ $8 \% \mathrm{NaCl}$ solution. After the resin's softening, the $\mathrm{Ca}^{2+}$ and $\mathrm{Mg}^{2+}$ in the water can be replaced by $\mathrm{Na}^{+}$, which can be cause water hardening. But the salt content of the treated water will not be reduced[5].

\subsection{Boiling Method}

When the Hard water boiled, the water contains $\mathrm{Ca}\left(\mathrm{HCO}_{3}\right)_{2}$ and $\mathrm{Mg}\left(\mathrm{HCO}_{3}\right)_{2}$ will be decomposed into insoluble $\mathrm{CaCO}_{3}$ and Slightly soluble $\mathrm{MgCO}_{3}$. The $\mathrm{MgCO}_{3}$ can react with water to produce more soluble $\mathrm{Mg}(\mathrm{OH})_{2}$ under the condition of further heating. But this method applies only to temporary hard water[4]. The chemical reaction equation is as follows.

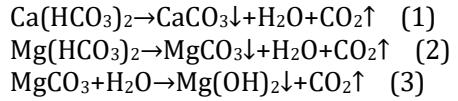

\subsection{Chemical Deposition Method}

For permanent hard water, because of $\mathrm{Ca}^{2}+$ and $\mathrm{Mg}^{2}+$ exist in sulfate or chloride formation, boiling method can not achieve the softening result. It can be remove by milk of lime and soda ash[6].

$4 \mathrm{Mg}^{2+}+\mathrm{Ca}(\mathrm{OH})_{2}+3 \mathrm{Na}_{2} \mathrm{CO}_{3} \rightarrow \mathrm{Mg}_{4}(\mathrm{OH})_{2}\left(\mathrm{CO}_{3}\right)_{3} \downarrow+\mathrm{Ca}^{2+}+6 \mathrm{Na}^{+}$

$\mathrm{Ca}^{2+}+\mathrm{Na}_{2} \mathrm{CO}_{3} \rightarrow \mathrm{CaCO}_{3} \downarrow+2 \mathrm{Na}^{+}$

For permanent hard water, we can use $\mathrm{Na}_{3} \mathrm{PO}_{4}$ or $\mathrm{Na}_{2} \mathrm{HPO}_{4}$ as precipitating agent to react with $\mathrm{Ca}^{2+}, \mathrm{Mg}^{2}+$ and generated $\mathrm{Ca}_{3}\left(\mathrm{PO}_{4}\right)_{2}$ and $\mathrm{Mg}_{3}\left(\mathrm{PO}_{4}\right)_{2}$. Do not need to filter, because the precipitation is loose and stable, it will not produce scale. So the water with nitrate precipitation can be sent to the boiler for use[7].

Common water softener: sodium phosphate, six sodium hexametaphosphate, amine derivatives(EDTA).

\section{The Transformation Mechanism of Permanent Hardness to Temporary Hardness by Ksp and $S$}

\subsection{Transformation of Permanent Hardness of the Same Type}

For the transformation of permanent hardness of the same type, it is suitable for $\mathrm{CaSO}_{4}$ transformation in hard water.

Hypothesis: $\mathrm{CaSO}_{4}(\mathrm{~s})+\mathrm{CO}_{3}{ }^{2-}(\mathrm{aq}) \leftrightarrows \mathrm{CaCO}_{3}(\mathrm{~s})+\mathrm{SO}_{4}{ }^{2-}(\mathrm{aq})$

So: $\mathrm{K}^{\theta}=\left[\mathrm{SO}_{4}{ }^{2-}\right] /\left[\mathrm{CO}_{3}{ }^{2-}\right]=\left[\mathrm{SO}_{4}{ }^{2-}\right] /\left[\mathrm{CO}_{3}{ }^{2-}\right.$

]$\times\left[\mathrm{Ca}^{2+}\right] /\left[\mathrm{Ca}^{2+}\right]=\mathrm{K}^{\Theta_{\mathrm{SP}}}\left(\mathrm{CaSO}_{4}\right) / \mathrm{K}^{\theta_{\mathrm{SP}}}\left(\mathrm{CaCO}_{3}\right)$

According to the related form. $\mathrm{K}^{\theta_{\mathrm{SP}}}\left(\mathrm{CaSO}_{4}\right)=2.45 \times 10^{-5}$, $\mathrm{K}^{\ominus}{ }_{\mathrm{SP}}\left(\mathrm{CaCO}_{3}\right)=8.7 \times 10^{-9}$, so $\mathrm{K}^{\ominus}=2.8 \times 10^{3}$. Because the $\mathrm{K}^{\ominus}$ indicates the extent of a reaction in this equation $\mathrm{K}^{\theta}=2.8 \times 10^{3}$. So the value of $\mathrm{K}$ is large. Precipitation transformation is quite completely. This equation is right. Thus, for the same type of precipitation, the precipitates with large solubility product $(\mathrm{KsP})$ can be easily transformed into the less solubility product(KSP) precipitation[8].

\subsection{Transformation of Permanent Hardness of the Different Type}

For the transformation of permanent hardness of the different type, it is suitable for $\mathrm{CaCl}_{2}, \mathrm{MgCl}_{2}$ and $\mathrm{MgSO}_{4}$ transformation in hard water.

Taking $\mathrm{CaCl}_{2}$ as an example. It is known that solubility(S) of $\mathrm{CaCl}_{2}$ is much larger than solubility $(\mathrm{S})$ of $\mathrm{CaCO}_{3}$.

Hypothesis: $\mathrm{Ca}^{2+}+\mathrm{CO}_{3}{ }^{2-} \leftrightarrows \mathrm{CaCO}_{3}(\mathrm{~s})$

So: $\mathrm{K}^{\theta}=1 /\left[\mathrm{Ca}^{2+}\right] \times\left[\mathrm{CO}_{3}^{2-}\right]=1 /\left[\mathrm{K}_{\mathrm{SP}}\left(\mathrm{CaCO}_{3}\right)\right]=1.1 \times 10^{8}$

In this Equation, precipitation transformation is quite completely. Thus, for the different types of precipitation, the precipitates with large solubility $(\mathrm{S})$ can be easily transformed into the less solubility(S) precipitation[8].

\section{The Correlation Between $\mathrm{CaSO}_{4}$ Content and Its Transformation}

According to $3.1 \mathrm{CaSO}_{4}(\mathrm{~s})+\mathrm{CO}_{3}{ }^{2-}(\mathrm{aq}) \leftrightarrows \mathrm{CaCO}_{3}(\mathrm{~s})+\mathrm{SO}_{4}{ }^{2}-(\mathrm{aq}), \mathrm{K}^{\ominus}=2.8 \times 10^{3}$ the value of $\mathrm{K}^{\ominus}$ is large, so precipitation transformation is quite completely. In order to further study the efficiency, the study finished the preparation of ten groups water with different content of $\mathrm{CaSO}_{4}$. Adding $1.06 \times 10^{-2}$ $\mathrm{mg} / \mathrm{L} \mathrm{Na} \mathrm{CO}_{3}$ solution, the amount of conversion was measured as shown in Table 1.

Table 1. The amount of conversion of $\mathrm{CaSO}_{4}$ in different concentration

\begin{tabular}{ccc}
\hline Serial number & $\begin{array}{c}\text { Concentration of } \mathrm{CaSO}_{4} \\
(\mathrm{mg} / \mathrm{L})\end{array}$ & $\begin{array}{c}\text { Amount of conversion of } \mathrm{CaSO}_{4} \\
(\mathrm{mg} / \mathrm{L})\end{array}$ \\
\hline 1 & 55 & 43.11 \\
2 & 110 & 98.32 \\
3 & 165 & 152.73 \\
4 & 220 & 208.49 \\
5 & 275 & 262.89 \\
6 & 330 & 318.65 \\
7 & 385 & 373.05 \\
8 & 440 & 428.81 \\
9 & 495 & 483.21 \\
10 & 550 & 537.61 \\
\hline
\end{tabular}

According to the data of table 1 set up the regression equation shown as Figure 1.

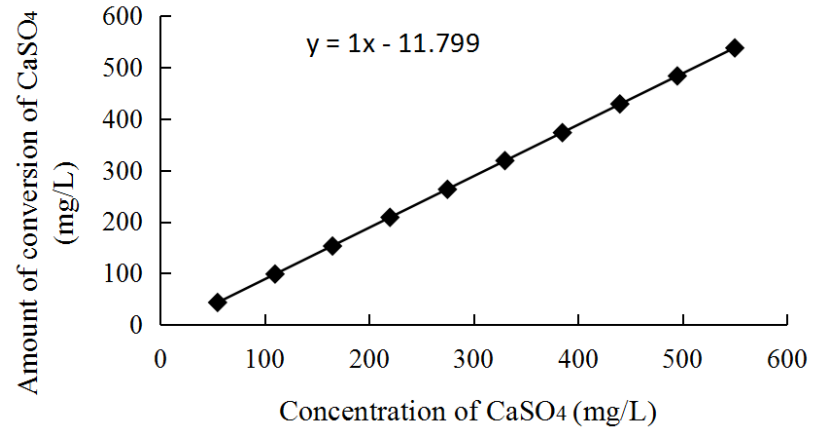

Figure 1. The correlation between the content of $\mathbf{C a S O}_{4}$ in different concentration and the amount of conversion

So the regression relation between $\mathrm{CaSO}_{4}$ content and the amount of its transformation is $\mathrm{y}=1.00 \mathrm{x}-11.799$.

Error analysis of the content of $\mathrm{CaSO}_{4}$ and its transformation as shown in Table 2.

Table 2. Error analysis of the amount of conversion of $\mathrm{CaSO}_{4}$ in different concentration

\begin{tabular}{|c|c|c|c|c|c|}
\hline \multirow{3}{*}{$\begin{array}{l}\text { Serial } \\
\text { numbe } \\
\quad \mathrm{r}\end{array}$} & \multirow{3}{*}{$\begin{array}{l}\text { Concentrati } \\
\text { on of CaSO } \\
(\mathrm{mg} / \mathrm{L})\end{array}$} & \multirow{2}{*}{\multicolumn{2}{|c|}{$\begin{array}{c}\text { Amount of conversion of } \\
\mathrm{CaSO}_{4} \\
(\mathrm{mg} / \mathrm{L}) \\
\end{array}$}} & \multirow{3}{*}{$\begin{array}{l}\text { Absolute } \\
\text { error }\end{array}$} & \multirow{3}{*}{$\begin{array}{l}\text { Relative } \\
\text { error } \\
(\%)\end{array}$} \\
\hline & & & & & \\
\hline & & $\begin{array}{l}\text { Measured } \\
\text { value }\end{array}$ & $\begin{array}{l}\text { Predictive } \\
\text { value }\end{array}$ & & \\
\hline 1 & 25 & 13.19 & 13.20 & 0.01 & 0.08 \\
\hline 2 & 80 & 68.14 & 68.20 & 0.06 & 0.09 \\
\hline 3 & 135 & 123.22 & 123.20 & -0.02 & -0.02 \\
\hline 4 & 190 & 178.57 & 178.20 & -0.37 & -0.02 \\
\hline 5 & 245 & 232.97 & 233.20 & 0.23 & 0.10 \\
\hline 6 & 300 & 288.73 & 288.20 & -0.53 & -0.02 \\
\hline 7 & 355 & 343.13 & 343.20 & 0.07 & 0.02 \\
\hline 8 & 410 & 397.53 & 398.20 & 0.67 & 0.02 \\
\hline 9 & 465 & 453.30 & 453.20 & 0.10 & 0.02 \\
\hline 10 & 520 & 507.69 & 508.20 & 0.51 & 0.01 \\
\hline \multicolumn{2}{|c|}{ Average value } & & & 0.073 & 0.028 \\
\hline
\end{tabular}

As shown in Table 2, between the measured and predicted values the maximum absolute error was 0.67 , the maximum relative error was $0.1 \%$, the average absolute error was 0.073 , and the average relative error was $0.028 \%$. Therefore, the prediction accuracy is high and reliable.

\section{Conclusions}

Suitable precipitation conversion agent can translate permanent hard water into temporary hard water effectively.

For the transformation of permanent hardness of the same type, it is 
suitable for $\mathrm{CaSO}_{4}$ transformation in hard water. For the transformation of permanent hardness of the different type, it is suitable for $\mathrm{CaCl}_{2}, \mathrm{MgCl}_{2}$ and $\mathrm{MgSO}_{4}$ transformation in hard water.

By linear regression equation, between the measured and predicted values the maximum absolute error was 0.67 , the maximum relative error was $0.1 \%$, the average absolute error was 0.073 , and the average relative error was $0.028 \%$. Therefore, the prediction accuracy is high and reliable.

\section{Acknowledgments}

This research was financed by the National Natural Science Foundation of China (No.31600253), the Science and Technology Department Foundation of Sichuan Province (No. 2017JY0087), the Education Department Foundation of Sichuan Province (No. 17ZA0409), The Teaching Reform Project Foundation of Chengdu University (CDJGB2017050) and the Excellence Project Foundation of Chengdu University (No.82502)

\section{References}

[1] Zhou X. L. (2010). Chemistry and life. Beijin: China Electric Power Press.
[3] Zhu J. C. (1981). Hard water. Beijin: Geological press.

[4] Sun M. (2003). Methods for softening hard water. Farm Machinery and Tractor Drives' Friend, 3: 289.

[5] Chen S., Yu X. L. (2013). Softening property of poly(acrylic acid-coacrylamide) superabsorbent resin to hard water. Journal of Wuhan Institute of Technology, 35(4): 39-42.

[6] Li X. L., Du X. (2015). The advantage of caustic soda used as hard water softeningagent. Metallurgical Power, 10: 61-63.

[7] Li Y. M., Zhou X. P. (2009). Damage caused by water hardness and its transformation. Charm China, 10: 54.

[8] Nanjing University. (2006). Inorganic and analytical chemistry. Beijin: Higher Education Press.

\section{About the Authors}

Yonggang Zeng(1980-), male, master degree, associate professor. The main research direction is water pollution control technology.

[2] Chen C. D. (2006). Water environment monitoring technology $Q \& A$. Beijin: Chemical industry press. 